University of New Hampshire

University of New Hampshire Scholars' Repository

Psychology Scholarship

College of Liberal Arts (COLA)

$2-1-2017$

\title{
Personality attributes that predict cadet performance at West Point
}

John D. Mayer

University of New Hampshire, Durham, jack.mayer@unh.edu

William Skimmyhorn

United States Military Academy, West Point

Follow this and additional works at: https://scholars.unh.edu/psych_facpub

Comments

This is an Author's Manuscript of an article published by Elsevier in Journal of Research in Personality in 2017,

available online: https://dx.doi.org/10.1016/j.jrp.2016.10.012. This manuscript version is made available under the CC-BY-NC-ND 4.0 license http://creativecommons.org/licenses/by-nc-nd/4.0/

\section{Recommended Citation}

Mayer, J. D. \& Skimmyhorn, W. (2017). Personality attributes that predict cadet performance at West Point. Journal of Research in Personality, 66, 14-26. DOI 10.1016/j.jrp.2016.10.012

This Article is brought to you for free and open access by the College of Liberal Arts (COLA) at University of New Hampshire Scholars' Repository. It has been accepted for inclusion in Psychology Scholarship by an authorized administrator of University of New Hampshire Scholars' Repository. For more information, please contact Scholarly.Communication@unh.edu. 


\title{
Personality Attributes That Predict Cadet Performance at West Point
}

\author{
John D. Mayer \\ University of New Hampshire \\ William Skimmyhorn \\ United States Military Academy, West Point
}

\section{Author Notes}

The authors are grateful to Luke B. Gallagher of the Office of Economic and Manpower Analysis, who managed the data files in these studies. Rachael Cavallaro and Tyler J. Mulcahy helped prepare the tables. Jayne Allen, Bonnie Barlow, Kateryna Sylaska, and Tyler Mulcahy all read and commented on an earlier draft of this work.

Correspondence regarding this article may be directed to either author: John D. Mayer, at 15 Academic Way, Department of Psychology, University of New Hampshire, 03824

jack.mayer@unh.edu; William Skimmyhorn at the Office of Economic and Manpower Analysis, Department of Social Sciences, Bldg 607, West Point, NY 10996, william.skimmyhorn $@$ usma.edu. For Skimmyhorn, the opinions expressed herein reflect the personal views of the authors and not those of the U.S. Army or the Department of Defense.

\begin{abstract}
Using data from the United States Military Academy at West Point collected in two successive years $(N=1102$ and $N=1049)$, we examined psychological measures and their correlations with consequential outcomes such as cadet performance at the Academy and leadership potential. We examined four broad intelligences, two of which were thing-focused (spatial and mathematical) and two people-focused (verbal and personal intelligences) and their predictions to thing- and people-centered courses (e.g., geology versus psychology); a thingpeople differential was present. The broad intelligences and the Big Five personality traits predicted performance criteria at consequential levels.

Keywords: Broad Intelligences, Spatial Intelligence, Personal Intelligence, Big Five, GPA, Military Performance, Personality

\section{Prepublication version of:}

Mayer, J. D. \& Skimmyhorn, W. (2017). Personality attributes that predict cadet performance at West Point. Journal of Research in Personality, 66, 14-26. DOI 10.1016/j.jrp.2016.10.012
\end{abstract}




\section{Personality Attributes That Predict Cadet Performance at West Point}

Personality can be regarded as the organization of a person's major psychological subsystems including an individual's intelligences, socio-emotional styles, self-control, and other qualities.(RW.ERROR - Unable to find reference:1053; Funder, 2013; Larsen \& Buss, 2008), Research indicates that traits from all these areas predict important criteria (Eysenck, 1998; Roberts, Kuncel, Shiner, Caspi, \& Goldberg, 2007). Since the mid-20 ${ }^{\text {th }}$ century, psychologists have been focused on better specifying these relationships, including their magnitudes and their applications to selection and training (e.g., Barrick \& Mount, 1991; Judge, Colbert, \& Ilies, 2004; Judge, Klinger, \& Simon, 2010; Schneider \& Newman, 2015). General mental ability is among the most important predictors, exhibiting relationships with school and work performance evaluations in the $r=.45$ to .55 range (Deary, 2012; Salgado, Anderson, Moscoso, Bertua, \& de Fruyt, 2003; Schmidt \& Hunter, 2004); non-ability traits predict career success as well, conscientiousness at $r=.22$ (Barrick \& Mount, 1991, p. 15).

Today, in the intelligence realm, increasing attention is paid to the differentiated intelligences that together make up general intelligence-referred to as broad intelligences (Schneider \& Newman, 2015). Contemporary researchers often depict mental abilities in a threetiered hierarchy with general intelligence - $g$ - atop two additional levels (McGrew, 2009). General intelligence concerns the capacity to carry out abstract reasoning, to recognize similarities and differences, to generalize, and to understand information in context (Gottfredson, 1997). Beneath $g$ at the second level is a set of between eight and sixteen broad intelligences, examples of which include verbal and spatial intelligences (Flanagan, Alfonso, Ortiz, \& Dynda, 2013; McGrew, 2009; Schneider \& Newman, 2015). ${ }^{1}$ Each broad intelligence has nested beneath it specific mental tasks that populate the lowest level of the three-stratum model. Verbal intelligence has nested within it vocabulary knowledge; spatial ability has beneath it the ability to rotate three-dimensional figures in one's mind.

Psychologists in the $20^{\text {th }}$ century studied broad intelligences that people used to reason about things: spatial intelligence had to do with objects in space; perceptual-organizational intelligence was focused on understanding mechanical parts and how they fit together. Over time, however, researchers in both animal and human cognition, have explored the idea that intelligence is concerned not only with things, but with people also. In primate cognition, attention focused increasingly on social cognition; in intelligence research, social, emotional, and intra- and interpersonal intelligences were proposed (Gardner, 1983; Salovey \& Mayer, 1990; Tomasello \& Call, 1997; Wong, Day, Maxwell, \& Meara, 1995). Broad intelligences may be organized along a continuum according to whether they concern things-so-called "thing" intelligences - as do spatial and perceptual-organizational intelligences, or whether they concern people - the hot intelligences - as do emotional and personal intelligences (Mayer, Salovey, \& Caruso, 2004).

People vary dramatically in their interests in things or people even at a very young age and these interests appear related to later intellectual development (RW.ERROR - Unable to find reference:1039; RW.ERROR - Unable to find reference:1006; Ackerman, 2014; Rolfhus \& Ackerman, 1999). In adulthood these differential interests are reflected in occupational choices: Mechanical engineers and accountants prefer to work with things; social workers and sales people prefer to work with people - and some like both (RW.ERROR - Unable to find reference:1007; RW.ERROR - Unable to find reference:1041). 
In the present study, we examine the personality attributes of two successive classes of cadets at West Point with a focus on their mental abilities, and also including the Big Five personality traits (Extraversion, Neuroticism, Openness, Agreeableness and Conscientiousness). We then correlate those traits with cadets' performance. We hope to replicate earlier findings such as that SAT and Conscientiousness scores can be used to estimate school performancehelpful amidst the current of uneasiness over non-replications in psychology (RW.ERROR Unable to find reference:1061).

However, our research goes well beyond this to focus on new phenomena: We will provide the first tests of whether personal intelligence-a newly-proposed broad intelligence about people - correlates with actual coursework and other matters of importance. Personal intelligence concerns the ability to reason about personality-both in oneself and in others. In addition, we will examine whether intelligences about things - spatial intelligence and SATMath, correlate most highly with performance in technical courses, whereas intelligences about people - represented by personal intelligence - correlate more highly with people-centered courses. Of more theoretical interest, personal intelligence has exhibited a unique pattern (among intelligences) of correlations with the Big Five, for example, with Agreeableness and Conscientiousness, and we will examine that relationship as well.

\section{The Three-Stratum Model of Intelligence}

The broad mental abilities are a diverse lot: Some pertain to memory: short-term memory intelligence and long-term memory retrieval ability; others concern mental processing speed (RW.ERROR - Unable to find reference:1055; Carroll, 1993; Flanagan et al., 2013; Schneider \& Newman, 2015). A second group of broad intelligences are distinguished according to domains of knowledge. For example, verbal intelligence includes vocabulary knowledge and sentence comprehension; perceptual-organizational involves skills such as knowing how things fit together. Particularly in adult development, people may develop mental abilities in areas of study and interest they pursue (Ackerman, 2014). These latter intelligences, in particular, can be thought of as varying along the thing - people continuum in their foci.

\section{Personal Intelligence as an Intelligence About People}

Personal intelligence was proposed as a potentially-unmeasured and overlooked broad intelligence at the end of the last decade (Mayer, 2008; Mayer, 2009). It involved the ability to reason about personality-relevant information in oneself and others. More specifically, people with personal intelligence were said to solve problems in areas that included (a) identifying personality-relevant information, (b) forming accurate models of one's own and others' personalities, (c) guiding choices using personality-relevant information and (d) systematizing one's goals accordingly.

The Test of Personal Intelligence can be used to measure personal intelligence; it consists of approximately 120 multiple-choice questions of the form:

A person is tactless and lacks a sense of humor. Which of the following is most likely to describe this person:
a. disagreeable
b. neurotic
c. carefree
d. desiring of attention

Here the answer is "a," disagreeable, because a lack of humor and tactlessness are instances of disagreeableness, according to research on the Big Five (Mayer, Panter, \& Caruso, 
2012). Items were divided into four areas of problem-solving proposed by the theory. Findings indicate that the overall Test of Personal Intelligence was reliable and that personal intelligence could be modeled as a single broad intelligence, using as indicators the four problem-solving areas of the theory. Personal intelligence scores resemble other broad intelligences in further ways as well: Test scores correlated about $r=.35$ with verbal intelligence and $r=.65$ with emotional intelligence, and also, like most other broad intelligences, about $r=.20$ with opennessclosedness (Mayer et al., 2012). But little is known about personal intelligence and its relations with real life phenomena: Do people with higher personal intelligence exhibit better college performance? Are they perceived differently from others? These and other questions are addressed here.

\section{The Thing-People Dimension}

Personal intelligence also may be related to a thing-people dimension, with broad intelligences such as spatial intelligence at one end, and personal intelligences at the other (RW.ERROR - Unable to find reference:1039). (An alternative label for this dimension is cool versus hot intelligences--Mayer \& Mitchell, 1998; Mayer et al., 2004). In addition to spatial intelligence, thing-focused intelligences also include quantitative-mathematical intelligence, with its focus on numbers and mathematical systems, and perceptual/organizational intelligence, which promotes problem solving in identifying how parts fit together, patterns and designs. In addition to personal intelligence, people focused-intelligences include emotional intelligence, which is focused on the ability to recognize and understand emotions in oneself and others.

The people intelligences are relatively new additions to the set of broad intelligences. Recently, however, researchers have found that emotional intelligence (measured as a mental ability) fits well with within the group (Legree et al., 2014; MacCann, Joseph, Newman, \& Roberts, 2014); personal intelligence is a still-more-recently proposed intelligence that is a likely candidate for inclusion (RW.ERROR - Unable to find reference:1027).

Predictions from broad intelligences. There is considerable evidence that many of the broad intelligences - particularly thing-related intelligences — predict consequential outcomes such as school and job performance (RW.ERROR - Unable to find reference:1029; RW.ERROR - Unable to find reference:1028; Deary, 2012; Schmidt \& Hunter, 2004). In our studies here, we suppose that thing intelligences will correlate with performance at thing focused tasks, and people intelligences will correlate with performance at people outcomes. This is consistent with earlier findings that broad abilities are differentially predictive of targeted outcomes. For example, emotional intelligence is related to better interpersonal outcomes (Mayer, Roberts, \& Barsade, 2008). By comparison, people high in spatial intelligence gravitate to more thingoriented fields such as the sciences and engineering, or move to visually-oriented aspects of more general fields such as choosing the visual arts over other artistic endeavors (Wai, Lubinski, \& Benbow, 2009).

\section{Relations to the Big Five}

Intelligences concerned with people may have different relationships with the Big Five personality traits than thing-focused intelligences because thinking about people may shape one's own traits. Higher thing-related intelligences typically correlate at around $r=.20$ with Openness (verbal more than others) and exhibit negative or near-zero correlations with the remaining Big Five (DeYoung, 2011). We believe that personal intelligence (and emotional intelligence) are likely to exhibit higher relationships with Agreeableness and with Conscientiousness (Joseph \& Newman, 2010; Mayer et al., 2012). In regard to personal intelligence, individuals with high people-focused understanding likely possess an advantage in 
choosing commitments they can meet because they better monitor their own personal strengths and weakness; as a consequence, they can better assess which commitments they are able to fulfill versus those for which their personal limits could prove to be obstacles. They also are likely to appreciate other people's individuality, and as a consequence, to better meet others' needs (if they wish to), and will therefore score higher on agreeableness than those lower in the skill.

\section{Introduction to the Present Studies}

To test whether intelligences correlates with certain outcomes, we will examine two classes of cadets who attended the Academy at West Point, evaluating the levels of their broad intelligences and comparing those with several academic and extracurricular outcomes. The Academy at West Point provides a four-year college education in which cadets complete a core academic curriculum consisting of slightly more than 20 courses divided among the liberal arts, sciences and engineering (Office of the Dean, 2014). The exact number depends on the student as some will place out of one or more courses or begin in an advanced-level course.

Our data set will include assessments of verbal, mathematical-quantitative, spatial, and personal areas of intelligence.

\section{Hypotheses}

We expected with some confidence to find that all four intelligence assessments, verbal, mathematical, spatial, and personal, would correlate positively with one another. This would provide new information about personal intelligence (which has been correlated only with a vocabulary measure before). We further expected the intelligences to be mostly independent of the Big Five traits, excepting for a low positive correlation with Openness.

Second, we expected that all the broad intelligences would correlate individually with overall academic performance at West Point.

Third, we hypothesized that spatial and personal intelligence would correlate with academic and other outcomes incrementally above the total SAT (often used as a proxy for general mental ability).

Fourth, we hypothesized that students' course performance would divide into thingversus-people centered course performance. That is, certain students would excel well in science and mathematics (thing-related), or in English, philosophy and other humanities (people-related), or in both, or in neither.

Fifth, we hypothesized that "thing" intelligences would correlate most highly with thingfocused courses and that "people" intelligences would exhibit their highest correlations with courses focused on people. We expected a similar pattern with the tactical officers' ratings of the cadets on thing- or person-related talents.

Sixth, we expected to find that self-control, as measured by conscientiousness in the Big Five would correlate with performance as well.

\section{Participants}

Participants were the members of two successive classes of cadets who attended the Academy at West Point in the early-to-mid 2010s. We will refer to the first-tested class as the Main sample; the second as the Replication sample.

Main Sample. Participants in the main sample were 1114 cadets in the graduating class of 2014 at West Point. The sample had an age range from 20 to $26(\mathrm{M}=21.72)$ and included 197 women and 905 men. The data allows for four categories of race/ethnicity. Eight hundred and 
twenty-six cadets identified as White, 80 as Black, 93 as Hispanic and 103 as Other (chiefly, Asian and Pacific Islander).

Replication Sample. Participants in the replication sample were 1049 cadets in the graduating class of 2015 at West Point. The sample had an age range from 19 to 25 ( $M=20.80)$ and included 174 women and 875 men. Seven hundred and forty-nine students identified in the four-category system as White, 105 as Black, 97 as Hispanic and 99 as Other.

\section{Methods}

\section{Materials: 1. Psychological Tests.} Measures of mental ability.

The SAT. In the main sample, 932 cadets and 893 cadets in the replication sample had SAT scores in their files, with subscores for verbal, mathematical and writing abilities (the latter was not used here).

The $O * N E T$ measure of Spatial Ability. Developed by the U.S. Department of Labor Employment and Training Administration, as part of the Occupation Net Ability Profiler (National Center for O*NET Development, 2015), the O*Net measure of Spatial Ability is a 20question test. Each question has a box to the left with a 2-dimensional cut-out-like depiction of a shape - in one example, a symmetrical cross with a square in the center. Test-takers must then pick one of four shapes to the right that would result if the shape were bent and/or folded into three dimensions (the cross-like object makes a box with an open top.

The TOPI 1.4. The Test of Personal Intelligence is an ability-based measure of reasoning about personality composed of 93 items with correct answers keyed to relevant research findings in personality psychology. Each item is in a multiple-choice format with four alternatives. For example, a sample question asks, "A person is straightforward and modest. Most likely, she also could be described as: (a) valuing ideas and beliefs, (b) active and energetic, (c) sympathetic and tender to others, and (d) self-conscious and anxious. The correct answer (as keyed to research with the Big Six, is "c". The test yields an overall score of personal intelligence and, in its more recent forms, two subscales (not scored here) (Mayer, Panter, \& Caruso, 2014). ${ }^{2}$

\section{Measures of socio-emotional styles and of self-control.}

The Five Factor Test. This 100-item measure of the big five draws its items from the International Personality Item Pool (RW.ERROR - Unable to find reference:1059; Goldberg et al., 2006), and the specific scale was downloaded from http://ipip.ori.org/newNEODomainsKey.htm. The measure includes 20 short phrases to reflect each of the five factors, for example, "Make people feel at ease" for Agreeableness and "Feel threatened easily" for Neuroticism. Responses are made on a 5-point scale from "Very Inaccurate" to "Very Accurate." In the Replication sample, the scale was trimmed, based on a factor analysis such that the revised scales had fewer items: Neuroticism to 11 items, Extraversion to 15, Openness, 14, Conscientiousness, 19 and Agreeableness, 19. This had negligible consequences for the scale reliabilities (see Table 2 footnote).

Grit. The 12-item Grit scale measures perseverance and goal-commitment under pressure (Duckworth, Peterson, Matthews, \& Kelly, 2007).

\section{Materials: 2. Outcome measures}

Course-Level and general academic performance. Academic performance was reflected by the cadets' GPA in individual courses from the core curriculum at the Military Academy. Twenty-six course GPAs were combined into the overall academic GPA. In few instances, the specific course GPA was drawn either from the basic course that most cadets took or from an 
advanced-placement alternative that the cadet substituted for the basic course. This likely added a small amount of noise to the data but otherwise left the data unaffected.

General military performance (reported on a GPA scale). The cadets' overall military performance can be thought of as an index of their job performance-the level at which they fulfill their military roles including carrying out jobs such as Squad Leader or Platoon Sergeant. Their performance in their $3^{\text {rd }}$ and $4^{\text {th }}$ years is regarded as reflecting their leadership abilities (Bartone, Snook, \& Tremble, 2002). Although general military performance involves jobs rather than courses, it is also reported at West Point on a GPA-like scale referred to as military GPA.

Physical performance scale (reported on a GPA scale). The cadets were also assigned a physical score that reflects a combination of their performance in physical education courses and their scores on tests of physical abilities and endurance, also reported on a GPA-like scale.

Tactical officers' Talent ratings. At the Academy at West Point, each officer-in-training is assigned a tactical officer who monitors their progress and provides counseling to them. The data we drew upon (see procedure) included the tactical officers' ratings of each cadet they supervised along 20 talents that ranged from communicator, to physically fit, to technologically adept. ${ }^{3}$ We employed three composite talent scores: (a) the overall average of a cadet's rated 20 talents, (b) their thing/technical-related talents including (1) detail-focused, (2) logical/analytical, (3) process disciplined, (4) spatially intelligent, and (5) technologically adept and their personrelated talents including (1) communicator, (2) cross-culturally fluent, (3) inspirational leader, (4) interpersonal, (5) introspective, (6) mentally tough, (7) perceptive/intuitive, (8) problemsolver, (9) project manager and (10) prudent risk taker. We also included the additional individual talent by itself in the leadership section.

Measures of Leadership. Leadership capacity is generally indexed at the Academy by military grades - representing military responsibilities - in the $3^{\text {rd }}$ and $4^{\text {th }}$ years (Bartone, Snook, Forsythe, Lewis, \& Bullis, 2007, p. 495; Kelly, Matthews, \& Bartone, 2014). In addition, we employed a diverse set of measures potentially related to leadership that included the number of officer positions the cadet held in campus clubs and organizations, and the number of captaincies in team sports.

Omitted Variables. For the purposes of keeping this article focused on the specific hypotheses, we omitted additional variables that were also available in the data file. These included the cadets' scores on the ACT (a second college admissions test), because they largely duplicated scores on the SAT and fewer cadets included them in their admissions materials. In addition, we omitted a second set of talent ratings pertaining to the cadets that were completed by officers who reviewed the cadets' total files, because their judgments were made with testscore and academic record information, and were potentially influenced by that information. A further group of other variables did not specifically relate to our hypotheses (e.g., on active duty; domestic/foreign exchange student).

\section{Procedure}

Our analyses drew on data collected in support of the Talent-Based Branching Program at West Point. The Talent-Based Branching program collects data about each cadet's skills, knowledge, and behaviors to help the Army and the cadets decide in which branch of the Army they are best fit to serve. Upon graduation from West Point, cadets are commissioned as officers in the U.S Army, and they then serve in one of seventeen basic branches including Infantry, the Corps of Engineers, and Military Intelligence.

Cadets in the two classes of 2014 and 2015 took the psychological tests online for the Talent-Based Branching program in one of several proctored mass-testing sessions. The cadets 
who took the test did so in a high-stakes environment in that they understood that (a) they would receive occupational counseling around the results, and (b) that the Talent-Based Branching Program officials would employ the results - along with other information - to determine whether the cadet would receive a military assignment that was their first, second, or lowerranked choice.

The testing used a secure survey response system operated by the United States Army. ${ }^{4}$ Cadets who were foreign exchange students, stationed overseas, or otherwise not available were contacted and logged into the system to take the tests on their own. The program also requested that the cadets complete an online resume to help demonstrate their talents to the Army in support of their branch assignments. This resume included a section about the cadet's leadership roles in clubs and sports. SAT scores, GPA, and other academic outcome variables were drawn from the students' administrative records.

Also for the program, tactical officers, who supervise groups of cadets in their daily activities, assess the cadets on a series of 20 talents - such as cross-culturally-fluent, mentally tough, and technologically adept; these tactical officers supervise roughly 30 cadets from each class year, providing them with feedback and counseling so as to guide them through their studies.

\section{Results}

\section{Focus on the Main Sample.}

Because the main and replication samples yielded very similar results, and because the main sample was substantial in size by itself, we will focus on results from the main Sample through most of the results. When we reach the key tests of relationships between the psychological measures and their outcomes, we will report results from both the main and replication samples.

\section{Preliminary Data Analyses}

Screening for Attentive Responding. Data from 1102 cadets made up the main sample, and 1049 for the replication. Their test data across the measures was inspected by Army Research Institute psychologists for random answers and long string responses (i.e., repeated choices such as "A...A...A...") and other signs of problematic responding. On that basis, 33 individuals in the Main sample and 23 in the Replication (less than 3\%) were flagged; they were asked to repeat the testing, in which case their original data was excluded.

Handling Missing Data. The testing system did not allow for omitted answers and there were therefore no missing data for the tests of spatial intelligence, personal intelligence, the big five traits or grit. Roughly $90 \%$ of the cadets - 932 and 893 - also had their SAT scores on file.

Tactical Officer Ratings. Tactical officers rated each of their supervisees on 20 talents. If they were unsure of a rating, they often left the survey item blank. We required at least 3 ratings within a category (thing-oriented, people-oriented) and 8 ratings to be present to calculate the total score, or otherwise coded the average rating as "missing"; there were 891, 987 and 962 usable responses in the main sample for the three composites, and 884, 1018, and 910 for the replication.

Other Issues. Cadets were encouraged to report their club leadership positions for the online resume (see Procedure). About a fifth of the cadets left these questions blank; given the context, we interpreted the blanks as a lack of leadership positions and recoded their responses as zeros. 
Summary. Most variables were complete for the full data set. The Ns for the central analyses ranged mostly upward from 932 to 1064 for the main sample and 883 to 1049 for the replication, with somewhat lower $N$ s for any results involving tactical officer ratings -884 for technical skills in the replication, the lowest.

\section{Table 1}

Means and Standard Deviations of Major Variables for the Main and Replication Samples

\begin{tabular}{|c|c|c|c|c|c|c|c|c|}
\hline \multirow[t]{2}{*}{ Major variables } & \multicolumn{4}{|c|}{ Main Sample } & \multicolumn{4}{|c|}{ Replication Sample } \\
\hline & $\mathrm{N}$ & Mean & SD & Range & $\mathrm{N}$ & Mean & $\mathrm{SD}$ & Range \\
\hline & \multicolumn{8}{|c|}{ Measures of Mental Ability } \\
\hline SAT Total & 932 & 1266.9 & 128.43 & $850-1600$ & 893 & 1261.9 & 134.7 & $820-1590$ \\
\hline SAT Verbal & 932 & 625.7 & 74.89 & $400-800$ & 893 & 621.8 & 77.45 & $390-800$ \\
\hline SAT Math & 932 & 641.2 & 70.43 & $400-800$ & 893 & 640.2 & 74.10 & $410-800$ \\
\hline Spatial intell. & 1064 & 16.6 & 3.87 & $0-20$ & 1036 & 17.4 & 2.64 & $5-20$ \\
\hline \multirow[t]{2}{*}{ Personal intell. } & 1063 & 78.5 & 10.64 & $21.5-95.7$ & 1037 & 80.7 & 10.57 & $15.1-98.8$ \\
\hline & \multicolumn{8}{|c|}{ Measures of Socio-Emotional and Self-Control ${ }^{\mathrm{a}}$} \\
\hline Extraversion & 1063 & 75.46 & 13.58 & $30-100$ & 1037 & 70.56 & 11.73 & $30-95$ \\
\hline Neuroticism & 1063 & 42.64 & 11.72 & $20-88$ & 1037 & 24.41 & 7.28 & $11-55$ \\
\hline Openness & 1063 & 72.52 & 11.29 & $37-99$ & 1037 & 43.41 & 6.83 & $14-70$ \\
\hline Agreeableness & 1063 & 74.87 & 9.64 & $30-98$ & 1037 & 45.55 & 6.42 & $19-92$ \\
\hline Conscientiousness & 1063 & 81.56 & 10.28 & $33-100$ & 1037 & 76.33 & 9.36 & $43-95$ \\
\hline \multirow[t]{3}{*}{ Grit } & 1063 & 46.28 & 5.62 & $20-59$ & 1037 & 46.46 & 5.41 & $24-60$ \\
\hline & \multicolumn{8}{|c|}{ Tactical Officer Talent Ratings } \\
\hline & \multicolumn{8}{|c|}{ Evaluations } \\
\hline Overall & 962 & 2.20 & .37 & $1.1-3$ & 910 & 2.30 & .43 & $1-3$ \\
\hline People talents & 987 & 2.16 & .43 & $1-3$ & 1018 & 2.23 & .49 & $1-3$ \\
\hline \multirow[t]{2}{*}{ Thing talents } & 891 & 2.21 & .39 & $1-3$ & 884 & 2.27 & .46 & $1-3$ \\
\hline & \multicolumn{8}{|c|}{ General Grades and Scores } \\
\hline Academic GPA & 1102 & 3.12 & .49 & $2.02-4.26$ & 1049 & 3.11 & .55 & $1.81-4.26$ \\
\hline Military point score & 1102 & 3.12 & .34 & $1.98-4.08$ & 1049 & 3.09 & .36 & $1.94-3.99$ \\
\hline \multirow[t]{2}{*}{ Physical point scores } & 1102 & 2.97 & .36 & $2.03-4.08$ & 1049 & 2.99 & .38 & $1.90-4.05$ \\
\hline & \multicolumn{8}{|c|}{ Broad Course Cluster GPAs and Scores } \\
\hline People courses & 1102 & 2.91 & .46 & $1.50-4.11$ & 1049 & 2.92 & .48 & $1.50-4.00$ \\
\hline \multirow[t]{2}{*}{\begin{tabular}{|l} 
Thing courses \\
\end{tabular}} & 1101 & 3.11 & .72 & $1.22-4.33$ & 1045 & 3.17 & .73 & $1.22-4.33$ \\
\hline & \multicolumn{8}{|c|}{ Leadership } \\
\hline Office-holding & 1102 & .18 & .61 & $0-6$ & 1049 & .11 & .45 & $0-5$ \\
\hline Presidencies & 1102 & .06 & .28 & $0-3$ & 1049 & .04 & .20 & $0-2$ \\
\hline Officerships & 1102 & .11 & .36 & $0-3$ & 1049 & .08 & .29 & $0-3$ \\
\hline Team captaincies & 1102 & .21 & .48 & $0-3$ & 1049 & .10 & .33 & $0-2$ \\
\hline Inspir. lead. rating-tac & 945 & 2.11 & .65 & $1-3$ & 952 & 2.23 & .70 & $1-3$ \\
\hline Inspir. lead. rating-file & 1020 & 2.05 & .70 & $1-3$ & 1030 & 2.24 & .69 & $1-3$ \\
\hline $3^{\text {rd }}$ and $4^{\text {th }}$ yr. lead. crs. & 1102 & 3.08 & .47 & $1.50-4.25$ & 1047 & 3.07 & .58 & $.50-4.16$ \\
\hline PL300 (lead. course) & 1101 & 3.15 & .60 & $1.0-4.33$ & 1012 & 3.10 & .66 & $0-4.33$ \\
\hline
\end{tabular}




\section{Means and Standard Deviations of the Key Variables.}

Table 1 reports the means, standard deviations, and range for the key variables of interest for both samples. These were organized into categories of (a) mental abilities, (b) socioemotional style and self-control, (c) observer-rated talents, (d) general grades and related scores, (e) broad course cluster grades, and (f) leadership variables.

\section{Correlations Among Groups of Psychological Variables}

Mental abilities measures. We had predicted that the broad intelligences would be moderately correlated with one another. The customary explanation for this ubiquitous finding is that all problem solving draws to some degree on $g$ - general intelligence. Table 2 (upper left) shows correlations in the main sample for the broad intelligences from $r=.56$ between math and verbal SATs to an $r=.17$ between both math SATs and personal intelligence, on the one hand, and verbal SAT and spatial intelligence, on the other. The positive manifold among these measures provides evidence that they are related intelligences - new information in regard to personal intelligence.

\section{Table 2}

Reliabilities and Correlations among Measures of Mental Ability, Socioemotional Style and Self-Control for the Main Sample

\begin{tabular}{|c|c|c|c|c|c|c|c|c|c|c|c|}
\hline & \multicolumn{5}{|c|}{ Measures of Intelligence } & \multicolumn{6}{|c|}{ Measures of Socio-affective and Self-Control } \\
\hline & \begin{tabular}{|l|} 
SAT \\
Total
\end{tabular} & \begin{tabular}{|l|} 
SAT \\
Verbal \\
\end{tabular} & $\begin{array}{l}\text { SAT- } \\
\text { Math }\end{array}$ & \begin{tabular}{|l} 
Spatial \\
intell.
\end{tabular} & $\begin{array}{l}\text { Person. } \\
\text { intell. }\end{array}$ & $\begin{array}{l}\text { Extra- } \\
\text { version }\end{array}$ & Neurot & \begin{tabular}{|l|} 
Open- \\
ness
\end{tabular} & $\begin{array}{l}\text { Agree- } \\
\text { able }\end{array}$ & Cns & Grit \\
\hline \multicolumn{12}{|l|}{ Mental Abilities } \\
\hline SAT Total & 1.00 & & & & & & & & & & \\
\hline SAT Verbal & $.89 * *$ & 1.00 & & & & & & & & & \\
\hline SAT Math & $.88 * *$ & $.56 * *$ & 1.00 & & & & & & & & \\
\hline Spatial intell. & $.26 * *$ & $.17 * *$ & $.31 * *$ & 1.00 & & & & & & & \\
\hline Personal int. & $.27 * *$ & $.30 * *$ & $.17 * *$ & $.23 * *$ & 1.00 & & & & & & \\
\hline \multicolumn{12}{|c|}{ Socio-emotional style and self-control } \\
\hline Extraversion & $-.27 * *$ & -.25 & -.23 & $-.07 *$ & $-.07 *$ & 1.00 & & & & & \\
\hline Neuroticism & .06 & .05 & .06 & -.03 & $-.07 *$ & $-.42 * *$ & 1.00 & & & & \\
\hline Openness & $.12 * *$ & $.22 * *$ & -.02 & .03 & $.11 * *$ & $.19 * *$ & $-.07 *$ & 1.00 & & & \\
\hline Agreeableness & $-.08 *$ & -.05 & -.09 & -.03 & $.16 * *$ & $.16 * *$ & $-.36 * *$ & $.22 * *$ & 1.00 & & \\
\hline Conscientious. & -.03 & -.02 & -.02 & $.07 *$ & $.15 * *$ & $.26 * *$ & $-.41 * *$ & $.08 *$ & $.26 * *$ & .00 & \\
\hline Grit & -.01 & .01 & -.03 & .05 & $.15 * *$ & $.20 * *$ & $-.39 * *$ & .06 & $.22 * *$ & $.75 * *$ & 1.00 \\
\hline Reliabilities* & na & na & na & .76 & .86 & .93 & .90 & .86 & .84 & .91 & .80 \\
\hline
\end{tabular}

*For the main sample. The Big Five scales were shortened slightly in the replication sample but the reliabilities were mostly unchanged; following the order of the table, they were: $.91, .87, .87, .80$, and .90 .

Measures of socio-emotional style and self-control. We further predicted that the broad intelligences would be mostly independent of the socioemotional and self-control traits that make up the big five. This, too, occurred, as shown in the lower left side of Table 2. There, the correlations ranged mostly between $r=-.10$ to +.10 , with several exceptions. As commonly is found, intelligences correlate positively with Openness, and in this sample, the $r=-.02$ to .22 , with verbal and personal intelligences accounting for the two highest positive correlations. 
Personal intelligence also correlated with Conscientiousness and Agreeableness, $r=.15$ and .16 $p<.001$, replicating a pattern exhibited in an earlier study (Mayer et al., 2012). The strongest relationship, however, was between extraversion and all the intelligences - particularly the total SAT, at $r=-.27$. Apparently, a touch of introversion contributes to one's performance at West Point Academy.

In the replication sample results (not shown) the intelligence measures exhibited very similar patterns of positive correlations with one another ranging from a low of $r=.17, p<.01$ between SAT Math and personal intelligence to a high of $r=.58, p<.01$, between SAT Math and Verbal. Also in the replication sample, SAT Verbal, SAT Math, spatial intelligence and personal intelligence correlated with openness: $r=.34, .16, .11$ and $.18, p s<.01$, respectively. Personal intelligence exhibited unique correlations with agreeableness and conscientiousness $r=$ .18 and $.19, p \mathrm{~s}<.01$. Once again, Extraversion exhibited a negative correlation with the SAT Total, $r=-.13$, but the relations were weaker than in the main sample. On the whole, these results indicate the customary relationships among broad intelligences and further suggest that some broad intelligences, particularly personal intelligence, might exhibit distinct relationships with the big five traits.

\section{Relations among Outcome Measures}

Academic, military and physical outcomes. Cadets who scored highly in one of the academy's three GPAs tended to do well in other areas of performance as well: In the main sample, cadets who were academically higher-performing did better at their military jobs, $r=.55$ and performed better physically, $r=.37$. Cadets with higher military GPAs also performed at higher physical levels, $r=.47$, all $p \mathrm{~s}<.01$. Results were similar in the replication group.

Tactical-officer talent ratings of cadets. The tactical officer talent ratings also exhibited a global effect in that cadets were often rated high or low across the twenty talents considered. The people- and thing-related talent ratings correlated $r=.66$ with one another; the two composites correlated $r=.94$ and .84 with the overall talent ratings. The correlations between the people and thing talents (which were independent of one another) suggest that the two composites are reasonably reliable.

Leadership variables. Leadership is a multifaceted concept and we examined the relations among (a) leadership experience as reflected by number of club officerships and team captaincies, (b) perceived leadership as reflected in the tactical officer and file-based talent ratings, (c) physical measures including height, weight and physical GPA, which may influence perceptions of leadership, and (d) military leader performance as reflected in $3^{\text {rd }}$ and $4^{\text {th }}$ year military GPA and a course in military leadership (PL300).

Aside from height and weight $(r=.71)$, the highest correlation of $r=.34$ was between the tactical officer's rating of inspirational leadership and the Year 3 and 4 military performance evaluations (see Table 3); it may have arisen because the raters were familiar with the cadets' performance in the military responsibilities. The next highest ratings, all in the vicinity of $r=.35$, $p$ s $<.01$, were among physical fitness, inspirational leadership ratings, $3^{\text {rd }}$ and $4^{\text {th }}$ year military grades reflective of leadership, and the academic course in leadership. Beyond those, correlations were slight. Being captain of an athletic team also correlated with physical fitness GPA, $r=.11$. Overall, holding a leadership position — club presidencies, officerships and team captainshipswas largely uncorrelated with academic or tactical-officer quality of leadership. In addition leadership-seeking and leadership-position-holding are independent of perceived leadership qualities. These findings are consistent with the oft-stated finding that leadership is a complex construct. 


\section{Table 3}

Correlations among Leadership Variables in the Main Sample

\begin{tabular}{|l|c|c|c|c|c|c|c|c|}
\hline & \multicolumn{2}{|c|}{$\begin{array}{c}\text { Club and Team } \\
\text { Experience }\end{array}$} & $\begin{array}{c}\text { Rated } \\
\text { Leadership }\end{array}$ & \multicolumn{2}{c|}{ Physical Qualities } & \multicolumn{2}{c|}{$\begin{array}{c}\text { Military Job and } \\
\text { Course Perform. }\end{array}$} \\
\hline & $\begin{array}{c}\text { Officer- } \\
\text { ships }\end{array}$ & $\begin{array}{c}\text { Team } \\
\text { captain- } \\
\text { cies }\end{array}$ & $\begin{array}{c}\text { Insp.- } \\
\text { leader-tac. }\end{array}$ & Height & Weight & Fitness & $\begin{array}{c}\text { Year 3 \& } \\
\text { 4 leader } \\
\text { GPA }\end{array}$ & Pl-300 \\
\hline Officerships & 1.00 & .02 & & & & & & \\
\hline Team captaincies & .01 & 1.00 & & & & & & \\
\hline Insp.-leader-tac & -.02 & $.10^{* *}$ & 1.00 & & & & & \\
\hline Height & $-.10^{* *}$ & -.02 & .05 & 1.00 & & & & \\
\hline Weight & $-.09^{* *}$ & .01 & -.03 & $.71^{* *}$ & 1.00 & & & \\
\hline Physical fit. pt. scr & -.02 & $.10^{* *}$ & $.24^{* *}$ & -.03 & $-.11^{* *}$ & 1.00 & & \\
\hline Year 3 \& 4 leader & .05 & .02 & $.34^{* *}$ & $-.13^{* *}$ & $-.22^{* *}$ & $.32^{* *}$ & 1.00 & \\
\hline PL-300 & -.03 & .02 & $.12^{* *}$ & -.01 & $-.10^{* *}$ & $.37^{* *}$ & $.36^{* *}$ & 1.00 \\
\hline
\end{tabular}

\section{Key Relationships between the Broad Intelligences and General Outcomes} Correlations between broad intelligences and overall academic, military and physical performance. To test our hypothesis that the broad intelligences would covary with broad academic performance among the cadets, we next correlated the broad intelligences with the various outcome measures. For each of the relationships between the broad intelligences and outcomes, we will focus the results on the main sample (Table 4, left); in most instances the values for the replication sample (Table 4 , right) were very similar.

The top rows of Table 4 (under "General Performance") contain the correlations between the various psychological predictors (columns) for both the main and replication samples, and the academic, military and physical GPAs (rows).

The overall SAT predicted academic performance in the main sample $r=.64$. Spatial and personal intelligences also predict GPA at levels of $r=.21$ and .18 respectively. SAT, spatial and personal intelligences also correlated with military job performance (military GPA) $r=.20, .12$, and .13 , respectively, $p s<.01$. SAT Total, SAT Math and spatial intelligence correlated with physical GPA at $r=.10, .15$ and .07 respectively, $p s<.01$.

The SAT scores, spatial intelligence and personal intelligences all correlated with the tactical officers' ratings from .08 to $.11, p s<.05$. Our hypothesis that the individual broad intelligences would correlate with academic outcomes was supported; they also related to military task performance and perceived talents.

Broad intelligences correlated with general outcomes even with SAT scores statistically controlled for. The relations between a given SAT area score and academic and military outcomes remained after partialing out the alternate SAT area score. That is, SAT-Math continued to predict overall academic GPA and military role performance at $r=.39$ and $.10 p$ s $<$ .01 in Study 1 and at the same levels $r=.39$ and $.10 p s<.01$ in Study 2. In turn, SAT-Verbal continued to predict overall academic GPA and military role performance at $r \mathrm{~s}=.34$ and $.10 p \mathrm{~s}<$ .01 in Study 1 and at the same levels $r \mathrm{~s}=.29$ and $.11 \mathrm{ps}<.01$ in Study 2. We conducted a still more stringent test of incremental validity for spatial and personal intelligence, controlling for SAT total scores-a proxy for general intelligence (Frey \& Detterman, 2004). This was, perhaps, overly strict as the SAT contains both some spatial and personal intelligence-related items, 
although that is not its focus. Perhaps predictably, the two measures failed the test for correlating with GPA in the Main Study, $r \mathrm{~s}=.02$ and .06 , n.s., although their predictions remained significant for military performance, $r s=.07, p<.05$ and $.09, p<.01$. Spatial intelligence fared about the same in the replication sample. Personal intelligence, however incrementally correlated with both academic and military performance in that sample, $r \mathrm{~s}=.11$ and $.11, p<.01$.

Table 4

\section{Predicting Consequential Outcomes from Measures of Mental Abilities}

\begin{tabular}{|c|c|c|c|c|c|c|c|c|c|c|}
\hline \multirow{2}{*}{$\begin{array}{l}\text { Outcome } \\
\text { Variables } \\
\end{array}$} & \multicolumn{5}{|c|}{ Main Sample } & \multicolumn{5}{|c|}{ Replication Sample } \\
\hline & $\begin{array}{l}\text { SAT } \\
\text { Total }\end{array}$ & $\begin{array}{l}\text { SAT } \\
\text { Verbal }\end{array}$ & $\begin{array}{l}\text { SAT- } \\
\text { Math }\end{array}$ & $\begin{array}{l}\text { Spatial } \\
\text { Intell. }\end{array}$ & $\begin{array}{l}\text { Pers. } \\
\text { Intell. }\end{array}$ & $\begin{array}{l}\text { SAT } \\
\text { Total }\end{array}$ & $\begin{array}{l}\text { SAT } \\
\text { Verbal }\end{array}$ & $\begin{array}{l}\text { SAT- } \\
\text { Math }\end{array}$ & $\begin{array}{l}\text { Spatial } \\
\text { Intell. }\end{array}$ & \begin{tabular}{|l|} 
Pers. \\
Intell.
\end{tabular} \\
\hline & \multicolumn{10}{|c|}{ General Outcomes } \\
\hline $\begin{array}{l}\text { Academic } \\
\text { point scale }\end{array}$ & $.64 * *$ & $.55^{* *}$ & $.58 * *$ & $.21 * *$ & $.18^{* *}$ & $.62 * *$ & $.53 * *$ & $.58^{* *}$ & $.17 * *$ & $.26 * *$ \\
\hline $\begin{array}{l}\text { Military point } \\
\text { scale }\end{array}$ & $.20 * *$ & $.18 * *$ & $.17 * *$ & $.12^{* *}$ & $.13^{* *}$ & $.22 * *$ & $.20 * *$ & $.19^{* *}$ & $.13 * *$ & $.16^{* *}$ \\
\hline $\begin{array}{l}\text { Physical point } \\
\text { scale }\end{array}$ & $.10 * *$ & .04 & $.15^{* *}$ & $.07 *$ & -.02 & .06 & .01 & $.10^{* *}$ & $.06^{*}$ & .04 \\
\hline \multirow[t]{2}{*}{$\begin{array}{l}\text { Talent rating } \\
\text { overall }\end{array}$} & $.10^{* * *}$ & $.08 *$ & $.10^{*}$ & $.09 * *$ & $.11^{* *}$ & $.10 * *$ & $.10 * *$ & $.08 *$ & $.07 *$ & $.11 * *$ \\
\hline & \multicolumn{10}{|c|}{ Tailored Outcomes: Course GPAs and Tactical Officer Ratings } \\
\hline People courses & $.62 * *$ & $.60 * *$ & $.49 * *$ & $.15^{* *}$ & $.22 * *$ & $.60 * *$ & $.56^{* *}$ & $.50 * *$ & $.12 * *$ & $.29 * *$ \\
\hline Thing courses & $.61 * *$ & $.45 * *$ & $.64 * *$ & $.24 * *$ & $.13^{* *}$ & $.63 * *$ & $.48 * *$ & $.64 * *$ & $.20 * *$ & $.22 * *$ \\
\hline People talents & .05 & .04 & .05 & .06 & $.10 * *$ & .07 & .07 & .05 & .06 & $.09 * *$ \\
\hline \multirow[t]{2}{*}{ Thing talents } & $.18^{* * *}$ & $.15 * *$ & $.16^{* *}$ & $.15^{* *}$ & $.12 * *$ & $.12 * *$ & $.10 * *$ & $.10 * *$ & .05 & $.11 * *$ \\
\hline & \multicolumn{10}{|c|}{ Leadership Outcomes } \\
\hline Office-holding & .04 & .05 & .02 & -.04 & -.02 & $.10 * *$ & $.09 * *$ & $.08 * *$ & .05 & .06 \\
\hline Team cpt. & .00 & -.02 & .02 & .03 & .01 & .00 & .01 & -.01 & -.00 & .05 \\
\hline Insp. lead.tac & .01 & .05 & -.05 & .05 & $.08^{*}$ & $.07 *$ & $.08 *$ & .06 & .02 & .05 \\
\hline $\begin{array}{l}3^{\text {rd }}-\text { and } 4^{\text {th }} \\
\text { years leader } \\
\text { performance }\end{array}$ & $.17 * *$ & $.15^{* *}$ & $.15^{* *}$ & $.09 * *$ & $.11^{* *}$ & $.18^{* *}$ & $.17 * *$ & $.15^{* *}$ & $.11 * *$ & $.12 * *$ \\
\hline $\begin{array}{l}\text { Leadership } \\
\text { course }\end{array}$ & $.35^{* *}$ & $.29 * *$ & $.32 * *$ & $.08^{* *}$ & $.19^{* *}$ & $.35 * *$ & $.32 * *$ & $.30 * *$ & .04 & $.21 * *$ \\
\hline
\end{tabular}

\section{A Test of the Thing-versus-People Performance Model in Academic Courses}

We hoped to create two composite variables for each cadet reflecting their performance across 26 required courses at the West Point: one variable reflecting performance at thingfocused courses from the math and physical sciences departments, and the other reflecting people-focused content from the humanities and social sciences departments. As a basis for the division, we first conducted an exploratory factor analysis of the student GPAs for the required courses in the Main sample using MPlus, and selecting a four factor solution: The first two factors corresponded to a thing-focused and people-focused course content. The third factor loaded two language courses and the fourth factor loaded two introductory history courses. We then confirmed the factor model on the same sample.

Good model fit is often regarded as a value of "near .95" as reflected by both the Confirmatory Fit Index (CFI) and Tucker-Lewis Index (TLI), and a Root Mean Square Error of 
Approximation (RMSEA) of less than .08 (Boomsma, Hoyle, \& Panter, 2012). After combining student GPAs in two chemistry courses, our model fit the Main sample well with $\chi(228)=$ $1229.49, \mathrm{CFI}=.95, \mathrm{TLI}=.95$ and RMSEA $=.06$. When we cross-validated the model on the Replication sample, the values were virtually identical, at $\chi(267)=1249.65, \mathrm{CFI}=.95, \mathrm{TLI}=.95$ and RMSEA = .06.

Based on these results, we created course composites of 8 thing-oriented courses and 18 people-oriented courses (we merged the $3^{\text {rd }}$ and $4^{\text {th }}$ factors with the $2^{\text {nd }}$ factor on the basis of the a priori classification of foreign language and history as humanities and their correlations of $r=$ .68 and .73 with the humanities factor).

Correlations between broad intelligences and tailored academic outcomes. We next examined the relationship between the cadets' performance on the thing- and people-related courses - and how highly the broad intelligence might correlate with those specific outcomes. We supposed that SAT-math scores and spatial intelligence would relate most closely to the thing area courses, and SAT-verbal and personal intelligence with the performance on peopleoriented courses. SAT-verbal did indeed correlate more highly with people-oriented courses than thing oriented courses $(r=.60$ versus .40$)$ and SAT math exhibited the reverse pattern $(r=.64$ versus .49). In a parallel fashion, personal intelligence correlated more highly with peopleoriented than thing oriented courses ( $r=.22$ versus .13) and spatial intelligence showed the reverse pattern, with thing-oriented courses predominant ( $r=.24$ versus .15$)$. These patterns were largely the same in the Replication sample. Table 5 includes the values and a statistical test for the difference between matched and mismatched pairing. The advantage for the matched versus the mismatched pairs is statistically significant in each case, across both the main and replication studies.

\section{Table 5}

Broad Intelligences and the Advantage of their Match with Person- and Thing-Related Courses

\begin{tabular}{|c|c|c|c|c|c|c|c|c|}
\hline & \multicolumn{4}{|c|}{ Main Sample } & \multicolumn{4}{|c|}{ Replication Sample } \\
\hline & SAT-V & SAT-M & Spatial & $\begin{array}{l}\text { TOPI } \\
1.4\end{array}$ & SAT-V & SAT-M & Spatial & TOPI 1.4 \\
\hline & \multicolumn{8}{|c|}{ Bivariate correlations } \\
\hline Overall GPA & $.55 * *$ & $.58 * *$ & $.21 * *$ & $.18^{* *}$ & $.53 * *$ & $.58 * *$ & $.17 * *$ & $.26^{* *}$ \\
\hline Person-focused & $.60 * *$ & $.49 * *$ & $.15 * *$ & $.22 * *$ & $.56 * *$ & $.50 * *$ & $.12 * *$ & $.29 * *$ \\
\hline Thing-focused & $.42 * *$ & $.64 * *$ & $.24 * *$ & $.13^{* *}$ & $.48^{* *}$ & $.64 * *$ & $.20 * *$ & $.22 * *$ \\
\hline \multirow[t]{2}{*}{ Pairwise $N^{*}$} & 931 & 932 & 1064 & 1063 & 893 & 893 & 1036 & 1037 \\
\hline & \multicolumn{8}{|c|}{$\begin{array}{l}\text { Advantage for rs between matched variables ("People" intelligence with } \\
\text { people-focused courses; "thing" intelligence with thing-focused courses) }\end{array}$} \\
\hline $\begin{array}{l}\text { Advantage for } \\
\text { matched } r\end{array}$ & .18 & .15 & .09 & .09 & .08 & .14 & .09 & .09 \\
\hline $\begin{array}{l}\text { Z-Test for } \\
\text { Difference in } r\end{array}$ & $9.84 * *$ & $8.62 * *$ & $4.15 * *$ & $4.13 * *$ & $4.87 * *$ & $8.91 * *$ & $5.16^{* *}$ & $3.69 * *$ \\
\hline $\begin{array}{l}\text { *Main Study, p } \\
* * \text { Where the } N \\
\text { Significance tes } \\
\text { http://www.psy }\end{array}$ & $\begin{array}{l}- \text { - with } \\
\text { unequ } \\
\text { ing }(S \\
\text { ke.col }\end{array}$ & ende & rrela & $\begin{array}{l}\text {.78; } \\
\text { repor } \\
3 \text { ) } \\
\text { ohp }\end{array}$ & $\begin{array}{l}\text { n Stuc } \\
\text { num. }\end{array}$ & & & \\
\hline
\end{tabular}


The specificity shows up less consistently for relations with perceived talents. There, personal intelligence was related to higher perceived talents in both the thing- and person- areas $(r \mathrm{~s}=.12$ and .10 in the Main sample and .11 and .09 in the replication, $p s<.05)$. Spatial intelligence showed only a statistically significant relationship with thing talents in the Main sample $(r=.15, p<.01)$.

Correlates with leadership outcomes. The broad intelligences also predicted some aspects of third and fourth-year military performance - which is regarded as an index of leadership - in the main sample at the $r=.07$ to .10 level with total SAT predicting $3^{\text {rd }}$ and $4^{\text {th }}$ year leader performance $r=.08$ and personal intelligence, $r=.11, p \mathrm{~s}<.01$. Values were similar in the replication sample.

Controlling for the influence of $g$ with partial correlations. Researchers view SAT Total scores as a reasonable proxy for general intelligence (Frey \& Detterman, 2004). In both samples, SAT Verbal and SAT Math predicted overall academic performance even after the other subtest scores have been controlled for. The two subtests also exhibited differential predictions: SAT Verbal with SAT Math scores partialed out, predicted verbal courses $r=.49$, and math courses $r$ $=.09$. SAT Math scores exhibited similar specificity: $r=.51$ with math compared to $r=.09$ for verbal courses.

Spatial and personal intelligences also exhibited unique predictions even after SAT Total scores are controlled. Personal intelligence predicted overall GPA with SAT partialed out, and only in the replication sample, $r=.11, p<.05$. Both spatial and personal intelligences correlated with overall military task performance (Military GPA) $r=.07$ to $.11, p s<.05$ to .01 in both the main and replication samples, as well as with tactical officer overall ratings in both samples, $r=$ .04 , n.s., to $.08, p$ s $<.05$.

With SAT Total controlled for, spatial intelligence exhibited incremental correlations with the math and spatial-ability course clusters at $r=.09$ and $.12, p s<.01$ for the main sample, but these relations were lower and nonsignificant in the replication.

Personal intelligence also correlated with the person-oriented military courses in both samples, with $r \mathrm{~s}=.09$ and $.11, p \mathrm{~s}<.05$. Personal intelligence exhibited incremental correlations for personality-related courses, at $r=.07, p<.05$ for the main sample and $r=.15, \mathrm{p}<.01$ for the replication. It further exhibited a correlation of $r=.08, \mathrm{p}<.05$ with tactical officers' overall ratings in both samples.

\section{Key Correlations with the Socio-Affective and Self-Control Measures}

Traits of socio-affective qualities and self-control also correlated highly with the outcomes - particularly self-reported self-control, as indicated in Table 6. Extraversion posed a non-specific impediment to high GPA in both samples $r=-.20$ and -.14, $p<.01$, and interfered more modestly with other academic criteria. Intellectual openness, on the other hand-which is correlated with actual intelligences - had a more positive non-specific effect on grades, $r=.08$ and .19 in the two samples, $p<0.1$ and $p<.01$ respectively.

Self-control - reflected in self-reports of conscientiousness and grit-had stronger effects: Conscientiousness correlated positively with all three GPA measures - academic, $r=.25$, military, $r=.40$ and physical, $r=.22, p \mathrm{~s}<.01$. Values in the replication sample were similar. Tactical officers also rated conscientious cadets higher in talents overall $r=.25$ and .24 across the two samples, $p s<.01$. The positive and nonspecific effects were reflected in the various correlations with the targeted course clusters, tactical officer ratings of inspirational leadership, and $3^{\text {rd }}$ and $4^{\text {th }}$-year military leadership. Grit, which correlated $r=.75$ and .74 with 
conscientiousness in the Main and Replication samples, had similar but generally weaker relationships (see Table 6).

\section{Table 6}

Predicting Consequential Outcomes from Socio-affective and Self-Control Measures

\begin{tabular}{|c|c|c|c|c|c|c|c|c|c|c|c|c|}
\hline & \multicolumn{6}{|c|}{ Main Sample } & \multicolumn{6}{|c|}{ Replication Sample } \\
\hline & \begin{tabular}{|l|} 
Extra- \\
version
\end{tabular} & Neurot & \begin{tabular}{|l|} 
Open- \\
ness
\end{tabular} & \begin{tabular}{|l|}
$\begin{array}{l}\text { Agree- } \\
\text { able }\end{array}$ \\
\end{tabular} & Cns & Grit & \begin{tabular}{|l|} 
Extra- \\
version
\end{tabular} & Neurot & $\begin{array}{l}\text { Open- } \\
\text { ness }\end{array}$ & $\begin{array}{l}\text { Agree- } \\
\text { able }\end{array}$ & Cns & Grit \\
\hline & \multicolumn{12}{|c|}{ General Academic Outcomes } \\
\hline $\begin{array}{l}\text { Academic } \\
\text { point scale }\end{array}$ & $-.20 * *$ & .05 & $.08^{*}$ & -.05 & $.25^{* *}$ & $.16^{* *}$ & $-.14 * *$ & .03 & $.20^{* * *}$ & -.03 & $.26^{* *}$ & $.10^{* *}$ \\
\hline $\begin{array}{l}\text { Military point } \\
\text { scale }\end{array}$ & .03 & $-.06 *$ & .02 & $.09 * *$ & $.40 * *$ & $.30 * *$ & .04 & .02 & $.08^{* * *}$ & $.07 *$ & $.40 * *$ & $.23 * *$ \\
\hline $\begin{array}{l}\text { Physical point } \\
\text { scale }\end{array}$ & $.10 * *$ & $-.13 * *$ & $-.07 *$ & .02 & $.22 * *$ & $.17 * *$ & .04 & -.01 & -.01 & .00 & $.18 * *$ & $.13 * *$ \\
\hline \begin{tabular}{|l|} 
Talent rating \\
overall
\end{tabular} & .06 & -.06 & .06 & .07 & $.25^{* *}$ & $.20 * *$ & $.10 * *$ & -.02 & .06 & .04 & $.24 * *$ & $.15 * *$ \\
\hline & \multicolumn{12}{|c|}{ Tailored Outcomes: Course GPAs and Tactical Officer Ratings } \\
\hline People courses & $-.18 * *$ & .04 & $.14 * *$ & -.02 & $.24 * *$ & $.18 * *$ & $-.10 * *$ & .02 & $.26 * *$ & -.03 & $.28 * *$ & $.12 * *$ \\
\hline Thing courses & $-.20 * *$ & .06 & -.01 & -.06 & $.17 * *$ & $.10^{*}$ & $-.17 * *$ & .01 & $.12 * *$ & -.04 & $.21 * *$ & $.16^{* * *}$ \\
\hline People talents & $.14 * *$ & $-.08 *$ & .06 & $.10 * *$ & $21 * *$ & $.17 * *$ & $.12 * *$ & -.04 & .06 & .06 & $.20 * *$ & $.12 * *$ \\
\hline Thing talents & .01 & .01 & $.08^{*}$ & .02 & $.23 * *$ & $.18 * *$ & .03 & -.05 & .04 & .03 & $.26 * *$ & $.16^{* *}$ \\
\hline & \multicolumn{12}{|c|}{ Leadership Outcomes } \\
\hline $\begin{array}{l}\text { Office- } \\
\text { holding }\end{array}$ & .00 & $.09 * *$ & $.07 *$ & .04 & -.02 & -.05 & $.06^{*}$ & -.05 & $.09 * *$ & .01 & .06 & .05 \\
\hline Team cpt. & $.10 * *$ & $-.07 *$ & .02 & .00 & .05 & .06 & .00 & $-.06^{*}$ & -.03 & .04 & $.09 * *$ & $.09 * *$ \\
\hline Insp. lead.tac & $.17 * *$ & $-.09 * *$ & $.08 *$ & $.07 *$ & $.20 * *$ & $.15^{* *}$ & $.08^{*}$ & .00 & .03 & .02 & $.18 * *$ & $.12 * *$ \\
\hline $\begin{array}{l}3^{\text {rd }}-\text { and } 4^{\text {th }} \\
\text { years leader } \\
\text { performance }\end{array}$ & -.04 & .00 & .01 & $.11 * *$ & $.30 * *$ & $.20 * *$ & -.01 & .04 & $.09 * *$ & $.07 *$ & $.32 * *$ & $.14 * *$ \\
\hline $\begin{array}{l}\text { Leadership } \\
\text { course }\end{array}$ & $-.08 *$ & .00 & .04 & -.01 & $.29 * *$ & $.20 * *$ & -.06 & .04 & $.13 * *$ & .02 & $.30^{* * *}$ & $.15^{* *}$ \\
\hline $\begin{array}{l}N \text { for the } \\
\text { measure }\end{array}$ & 1063 & 1063 & 1063 & 1063 & 1063 & 1063 & 1037 & 1037 & 1037 & \begin{tabular}{|l}
1037 \\
\end{tabular} & \begin{tabular}{|l}
1037 \\
\end{tabular} & \begin{tabular}{|l}
1037 \\
\end{tabular} \\
\hline
\end{tabular}

\section{Discussion}

\section{Summary of Results}

In the main sample and its replication, we examined the relationship between psychological variables and consequential outcomes among cadets at the United States Military Academy at West Point, focusing on relations between broad intelligences and outcomes including cadet academic performance, performance of military responsibilities, physical ability, and leadership. A number of the psychological variables were uniquely related to outcomes, particularly in the areas of performance of academic and military performance. 


\section{Learning About Broad Intelligences}

We have noted that much of the $20^{\text {th }}$ century was focused on understanding the role of general intelligence in predicting key life outcomes, but that since that time, psychologists have begun to focus on broad intelligences such as spatial, personal, quantitative, verbal and other areas of mental capacity. In this study we examined four broad intelligences and their interrelationships.

Positive manifold among intelligences - including personal intelligence. For example, this was the first study to show that personal intelligence, when observed among multiple broad intelligences, shares with them a consistent a pattern of positive relations - a correlation matrix with positive values termed a positive manifold - that is a hallmark of mental abilities. The earlier finding that personal intelligence correlated with vocabulary ability is now generalized to the broader skills of the SAT-verbal test, as well as to SAT-quantitative and spatial intelligence. This provides key further evidence of the likelihood that personal intelligence is a broad intelligence like those others.

Broad intelligences exhibit distinguishable patterns with the big five. Several of the broad intelligences studied here also exhibited distinct patterns of (low-positive) relationships with the traits of socioemotional style and self-control found in the commonly studied Big Five. Intelligence researchers commonly remark that general intelligence is related to openness-but the results here indicate that the relationship is stronger for some broad intelligences than others. In Study 1, SAT-verbal and personal intelligence correlated with psychological openness, but SAT-math or spatial intelligence did not; in Study 2, all four broad intelligences correlated with openness, but SAT-verbal and personal intelligence exhibited correlations at twice the level of SAT-math and spatial intelligence $(r s=.34$ and .19 versus .16 and .11$)$.

Personal intelligence also exhibited correlated with agreeableness and conscientiousness in both studies (Study $1 r \mathrm{~s}=.16$ and .15; Study $2 r \mathrm{~s}=.18$ and $.16, p s<.001$ ), whereas no other broad intelligence in these studies exhibited significant positive correlations with those traits, excepting one non-replicated $r=.07$ between spatial intelligence and conscientiousness in Study 1. By comparison, according to one review, emotional intelligence does correlate $r=.25$ with agreeableness and .12 with conscientiousness across studies (Joseph \& Newman, 2010, Table 2). Personal intelligence may show the reverse pattern with conscientiousness and agreeableness, correlating more highly with conscientiousness as it did here and in Study 3 of an earlier publication that correlated the tests (Mayer et al., 2012, Study 3).

\section{Correlations with Real-Life Criteria}

The effects of general intelligence and general effort. One reason that intelligences are studied as heavily as they are, is their consistent prediction of performance at school and on the job. All four broad intelligences studied here were correlated with academic performance. That was no surprise regarding the SAT-verbal and SAT-math scores, as those are designed for that purpose, and spatial intelligence has shown important predictions in this area previously as well (Wai et al., 2009). This was the first demonstration that personal intelligence also relates to actual academic performance.

All four intelligences also correlated with military performance (reflected by the military point scale rating). Once again, this is the first time that personal intelligence has been correlated with on-the-job performance (or, at least, performance in job-preparation situations) and it was 
effective at predicting outcomes — as did the other measures. The correlations between personal intelligence predicted these outcomes even when SAT scores were controlled for.

Broad intelligences and general and tailored outcomes. One of our key hypotheses was that broad intelligences would correlate with performance at tasks tailored to the specific intelligence more highly than with general criteria. Our test of that hypothesis was facilitated by our finding that we could model West Point cadets' course performance according to whether the cadets were good at thing/technical courses, people-courses, both, or neither. (Two far smaller factors loaded foreign languages and history; only the foreign languages factor was still robust in the Replications sample). Using thing- and person-based course composites, we found that SATverbal and personal intelligence correlated with heightened performance at person-centered courses; SAT-math and spatial intelligence correlated with heighted performance at technicalcentered courses.

Correlations and incremental validity of broad intelligences for military and leadership performance. Personal intelligence, and to a lesser extent spatial intelligence, were also related to $3^{\text {rd }}$-and $-4^{\text {th }}$ year performance, which is regarded as especially indicative of leadership, at $r \mathrm{~s}=$ .09 and .11 in the Main Sample and $r s=.11$ and .12 in the Replication Sample, $p s<.01$ (Bartone et al., 2002; Kelly et al., 2014).

Office-holding appeared to be distinct from talent at leadership. None of the intellectual, socio-emotional style or self-control variables correlated with actual office-holding and team captaincies across the two studies with consistency.

The Performance of the Big Five. The traits of the big five also correlated with academic and other outcomes in robust ways. Conscientiousness in particular revealed across-the-board relationships with academic GPA, military performance and physical achievements in both studies, in the $r=.20$ to .40 range. Conscientiousness similarly correlated with overall talent ratings by tactical officers at about $r=.25$ range across samples, and with leadership as reflected in $3^{\text {rd }}$ and $4^{\text {th }}$-year military performance in the vicinity of $r=.30$ across samples. These findings are of theoretical importance and of practical interest.

The Big Five trait of conscientiousness-carelessness is a robust correlate of consequential outcomes, but applied psychologists have noted that it is reasonably easy to "fake high" on conscientiousness and have explored some of the conditions on which this occurs (Birkeland, Manson, Kisamore, Brannick, \& Smith, 2006; Komar, Brown, Komar, \& Robie, 2008; Peterson, Griffith, Isaacson, O'Connell, \& Mangos, 2011). There was, however, no restriction of range (i.e., no suggestion that everyone claimed high scores) in comparison to a low-stakes comparison group (RW.ERROR - Unable to find reference:1059). It may be that cadets acknowledged their low conscientiousness because they are honest and direct under most or all circumstances, including high stakes testing.

If so, however, it raises the question of whether other populations of test-takers outside of West Point would be similarly frank about themselves. Alternatively, perhaps the cadets (and people more generally) who endorse items reflecting their low conscientiousness might simply be unaware of the use to which their self-acknowledged carelessness could be put. If the latter were the case, and public awareness of the importance of self-reported conscientiousness to selection rose, test-takers could learn to change their answers under high stakes conditions and thereby reduce the validity of the tests' predictions over time.

\section{Practical Considerations}

We have found that broad intelligences have their own unique signatures and predictive power. Existing testing programs require little modification to include broad intelligences, and 
research models that include them fit data better than those using general intelligence alone. Differentiated mental abilities such as spatial and emotional intelligences, and mathematical and verbal problem-solving may heighten predictions over the use of $g$ alone at levels of about 2-6\% variance-with partial correlations controlling for $g$ between $r=.14$ and .24 (Ackerman, 2014; Schneider \& Newman, 2015). Human being employ many broad intelligences — and they excel at many different outcomes.

Under conditions specified by Rosenthal and Rubin (Rosenthal \& Rubin, 1982; Rosenthal, 1990) an incremental correlation of $r=.1$ can reclassify $10 \%$ of a population more accurately as to whether their performance will be above or below average. The research here and elsewhere indicates that the use of $g$ and broad intelligence scores together would incrementally predict consequential outcomes at about that level.

Scales of broad intelligence also arguably deliver a fairer testing experience for the testtaker. Several decades ago, Howard Gardner sparked the public's imagination about mental abilities beyond general intelligence with a book on multiple intelligences (Gardner, 1983). There were drawbacks to Gardner's work: He was reluctant to acknowledge the contributions of intelligence testing to our understanding of human abilities and discouraged the development of intelligence tests to evaluate his own theory (Gardner, 1983, p. 16; Gardner, 1999, p. 16; Hunt, 2011; Sternberg, 1984; Visser, Ashton, \& Vernon, 2006). The more contemporary concept of broad intelligences recognizes the fundamental empirical realities of $g$ and at the same time allows for a consideration of people's strengths in broad ability areas.

If the popularity of Gardner's theory was any indication, test-takers desire to have their basic skills in multiple areas described and recognized. It seems likely that test-takers prefer the more tailored information provided by multiple valid score reports. These multiple ability measures have the additional advantage of being reasonably relatively resistant to faking.

\section{Study Limitations}

There are some limits as regards the generalizability of our findings. The two samples, although large, both drew on cadets at the Military Academy at West Point, who are not entirely representative of the US population: The cadets are highly talented individuals relative to the general population, are predominantly male, and have greater interests in engineering and the military than is typical. We have no theoretical reason to believe that this sample's characteristics might limit the generalization of the findings other than possibly restricting the range of certain variables and therefore underestimating the correlations reported here, but there could be additional factors that render the results different from those of the general population.

A second limitation is that the present study examined just four broad mental abilities out of up to a dozen more that might have been included, from auditory ability to memory retrieval capacity (Carroll, 1993; Flanagan et al., 2013; McGrew, 2009). A further limitation is modest strength of the relationships reported. Although the correlations al predictions appear stable and replicable, they are, on the whole, short of eye-popping in their levels. This is often the reality of correlational relations from personality to major life outcomes: Other factors including situational influences, chance events, and, no doubt, psychological qualities that have been omitted here — perhaps not yet even imagined — may ultimately contribute. That limitation acknowledged, stable, predictable correlations can add to our understanding and practical decisions regarding selection.

\section{Concluding Comment}

Applied research in mental abilities today can be thought of as following two tracks: refinement of what we already know, and exploration of what we do not. The present studies 
helped refine what we already know: The inclusion of broad intelligences can often enhance correlations with key criteria. They also continue exploration into what we do not yet know: This was the first large sample study to to compare personal intelligence with abilities such as spatial intelligence, verbal intelligence, and mathematical reasoning. It was also the first to correlate personal intelligence with consequential outcomes such as academic and military task performance. These relationships are useful to understand because they can be used to enhance people's knowledge as to their strengths and weaknesses, and, if they so desire, to train them to higher levels in areas of their choice both to guide people toward careers at which they will be good.

\section{References}

Ackerman, P. L. (2014). Adolescent and adult intellectual development. Current Directions in Psychological Science, 23(4), 246-251.

Barrick, M. R., \& Mount, M. K. (1991). The big five personality dimensions and job performance: A meta-analysis. Personnel Psychology, 44(1), 1-26.

Bartone, P. T., Snook, S. A., Forsythe, G. B., Lewis, P., \& Bullis, R. C. (2007). Psychosocial development and leader performance of military officer cadets. The Leadership Quarterly, 18(5), 490-504. doi:10.1016/j.leaqua.2007.07.008

Bartone, P. T., Snook, S. A., \& Tremble, T. R. J. (2002). Cognitive and personality predictors of leader performance in west point cadets. Military Psychology, 14(4), 321-338.

Birkeland, S. A., Manson, T. M., Kisamore, J. L., Brannick, M. T., \& Smith, M. A. (2006). A meta-analytic investigation of job applicant faking on personality measures. International Journal of Selection and Assessment, 14(4), 317-335.

Boomsma, A., Hoyle, R. H., \& Panter, A. T. (2012). The structural equation modeling research report. In R. H. Hoyle, \& R. H. (. Hoyle (Eds.), (pp. 341-358). New York, NY, US: Guilford Press. Retrieved from http://search.ebscohost.com/login.aspx?direct=true \&db=psyh\&AN=2012-16551021\&site=ehost-live

Carroll, J. B. (1993). Human cognitive abilities: A survey of factor-analytic studies. New York, NY US: Cambridge University Press.

Deary, I. J. (2012). Intelligence. Annual Review of Psychology, 63, 453-482. doi:10.1146/annurev-psych-120710-100353

DeYoung, C. G. (2011). Intelligence and personality. In R. J. Sternberg, S. B. Kaufman, R. J. (. Sternberg \& S. B. (. Kaufman (Eds.), (pp. 711-737). New York, NY, US: Cambridge University Press. doi:10.1017/CBO9780511977244.036

Duckworth, A. L., Peterson, C., Matthews, M. D., \& Kelly, D. R. (2007). Grit: Perseverance and passion for long-term goals. Journal of Personality and Social Psychology, 92(6), 10871101.

Eysenck, H. (1998). Dimensions of personality. Piscataway, NJ, US: Transaction Publishers. Flanagan, D. P., Alfonso, V. C., Ortiz, S. O., \& Dynda, A. M. (2013). Cognitive assessment: Progress in psychometric theories of intelligence, the structure of cognitive ability tests, and interpretive approaches to cognitive test performance. In D. H. Saklofske, C. R. Reynolds, V. L. Schwean, D. H. Saklofske, C. R. Reynolds \& V. L. Schwean (Eds.), (pp. 239-285). New York, NY, US: Oxford University Press. 
Frey, M. C., \& Detterman, D. K. (2004). Scholastic assessment or g? the relationship between the scholastic assessment test and general cognitive ability. Psychological Science, 15(6), 373-378.

Funder, D. C. (2013). The personality puzzle (6th ed.). New York: W. W. Norton.

Gardner, H. (1983). Frames of mind: The theory of multiple intelligences. New York, NY US: Basic Books.

Gardner, H. (1999). Intelligence reframed: Multiple intelligences for the 21st century. New York, NY, US: Basic Books.

Goldberg, L. R., Johnson, J. A., Eber, H. W., Hogan, R., Ashton, M. C., Cloninger, C. R., \& Gough, H. G. (2006). The international personality item pool and the future of publicdomain personality measures. Journal of Research in Personality, 40(1), 84-96.

Gottfredson, L. S. (1997). Mainstream science on intelligence: An editorial with 52 signatories, history and bibliography. Intelligence, 24(1), 13-23. doi:10.1016/S0160-2896(97)90011-8

Hunt, E. (2011). Human intelligence. New York, NY, US: Cambridge University Press.

Joseph, D. L., \& Newman, D. A. (2010). Emotional intelligence: An integrative meta-analysis and cascading model. Journal of Applied Psychology, 95(1), 54-78. doi:10.1037/a0017286

Judge, T. A., Colbert, A. E., \& Ilies, R. (2004). Intelligence and leadership: A quantitative review and test of theoretical propositions. Journal of Applied Psychology, 89(3), 542-552.

Judge, T. A., Klinger, R. L., \& Simon, L. S. (2010). Time is on my side: Time, general mental ability, human capital, and extrinsic career success. Journal of Applied Psychology, 95(1), 92-107.

Kelly, D. R., Matthews, M. D., \& Bartone, P. T. (2014). Grit and hardiness as predictors of performance among west point cadets. Military Psychology, 26(4), 327-342.

Komar, S., Brown, D. J., Komar, J. A., \& Robie, C. (2008). Faking and the validity of conscientiousness: A monte carlo investigation. Journal of Applied Psychology, 93(1), 140154.

Larsen, R. J., \& Buss, D. M. (2008). Personality psychology: Domains of knowledge about human nature. Boston, MA: McGraw Hill.

Legree, P. J., Psotka, J., Robbins, J., Roberts, R. D., Putka, D. J., \& Mullins, H. M. (2014). Profile similarity metrics as an alternate framework to score rating-based tests: MSCEIT reanalyses. Intelligence, 47, 159-174. doi:10.1016/j.intell.2014.09.005

MacCann, C., Joseph, D. L., Newman, D. A., \& Roberts, R. D. (2014). Emotional intelligence is a second-stratum factor of intelligence: Evidence from hierarchical and bifactor models. US: American Psychological Association.

Mayer, J. D. (2008). Personal intelligence. Imagination, Cognition and Personality, 27(3), 209232. doi:10.2190/IC.27.3.b

Mayer, J. D. (2009). Personal intelligence expressed: A theoretical analysis. Review of General Psychology, 13(1), 46-58. doi:10.1037/a0014229

Mayer, J. D., \& Mitchell, D. C. (1998). Intelligence as a subsystem of personality: From spearman's $g$ to contemporary models of hot processing. In W. Tomic, \& J. Kingma (Eds.), Advances in cognition and educational practice (pp. 43-75). Greenwich, CT: JAI Press.

Mayer, J. D., Panter, A. T., \& Caruso, D. R. (2012). Does personal intelligence exist? evidence from a new ability-based measure. Journal of Personality Assessment, 94, 124-140. doi:10.1080/00223891.2011.646108

Mayer, J. D., Panter, A. T., \& Caruso, D. R. (2014). Test of personal intelligence (TOPI 1.4) manual. (). Durham, NH: University of New Hampshire. 
Mayer, J. D., Roberts, R. D., \& Barsade, S. G. (2008). Human abilities: Emotional intelligence. Annual Review of Psychology, 59, 507-536. doi:10.1146/annurev.psych.59.103006.093646

Mayer, J. D., Salovey, P., \& Caruso, D. R. (2004). Emotional intelligence: Theory, findings, and implications. Psychological Inquiry, 15(3), 197-215.

McGrew, K. S. (2009). CHC theory and the human cognitive abilities project: Standing on the shoulders of the giants of psychometric intelligence research. Intelligence, 37(1), 1-10. doi:10.1016/j.intell.2008.08.004

National Center for O*NET Development. (2015). Ability profiler (AP). O*NET resource center. Retrieved from http://www.onetcenter.org/AP.html

Office of the Dean. (2014). United states military academy academic program class of 2016. curriculm and course description. West Point, NY: United States Military Academy.

Peterson, M. H., Griffith, R. L., Isaacson, J. A., O'Connell, M. S., \& Mangos, P. M. (2011). Applicant faking, social desirability, and the prediction of counterproductive work behaviors. Human Performance, 24(3), 270-290.

Roberts, B. W., Kuncel, N. R., Shiner, R., Caspi, A., \& Goldberg, L. R. (2007). The power of personality: The comparative validity of personality traits, socioeconomic status, and cognitive ability for predicting important life outcomes. Perspectives on Psychological Science, 2(4), 313-345. doi:10.1111/j.1745-6916.2007.00047.x

Rolfhus, E. L., \& Ackerman, P. L. (1999). Assessing individual differences in knowledge: Knowledge, intelligence, and related traits. Journal of Educational Psychology, 91(3), 511526. doi:10.1037/0022-0663.91.3.511

Rosenthal, R. (1990). How are we doing in soft psychology? American Psychologist, 45(6), 775 777. doi:10.1037/0003-066X.45.6.775

Rosenthal, R., \& Rubin, D. B. (1982). A simple, general purpose display of magnitude of experimental effect. Journal of Educational Psychology, 74(2), 166-169. doi:10.1037/00220663.74.2.166

Salgado, J. F., Anderson, N., Moscoso, S., Bertua, C., \& de Fruyt, F. (2003). International validity generalization of GMA and cognitive abilities: A european community metaanalysis. Personnel Psychology, 56(3), 573-605.

Salovey, P., \& Mayer, J. D. (1990). Emotional intelligence. Imagination, Cognition and Personality, 9(3), 185-211.

Schmidt, F. L., \& Hunter, J. (2004). General mental ability in the world of work: Occupational attainment and job performance. Journal of Personality and Social Psychology, 86(1), 162173.

Schneider, W. J., \& Newman, D. A. (2015). Intelligence is multidimensional: Theoretical review and implications of specific cognitive abilities. Human Resource Management Review, 25(1), 12-27.

Sternberg, R. J. (1984). Fighting butter battles: A reply. Phi Delta Kappan, 65(10), 700-700.

Tomasello, M., \& Call, J. (1997). Primate cognition. New York, NY, US: Oxford University Press. Retrieved from http://search.ebscohost.com/login.aspx?direct=true\&db=psyh\&AN=1997-36461000\&site=ehost-live

Visser, B. A., Ashton, M. C., \& Vernon, P. A. (2006). Beyond g: Putting multiple intelligences theory to the test. Intelligence, 34(5), 487-502. doi:10.1016/j.intell.2006.02.004 
Wai, J., Lubinski, D., \& Benbow, C. P. (2009). Spatial ability for STEM domains: Aligning over 50 years of cumulative psychological knowledge solidifies its importance. Journal of Educational Psychology, 101(4), 817-835.

Wong, C. T., Day, J. D., Maxwell, S. E., \& Meara, N. M. (1995). A multitrait-multimethod study of academic and social intelligence in college students. Journal of Educational Psychology, 87(1), 117-133. doi:10.1037/0022-0663.87.1.117

\section{Footnotes}

1. The broad intelligences of the three-stratum model of intelligences may bring to mind Howard Gardner's (Gardner, 1983) theory of multiple intelligences, but Gardner's model implied that the intelligences were independent of one another rather than related.

2. The 93 item TOPI 1.4 was created as a subset of the TOPI 1.2Rf, a reformatted version of the TOPI 1.2. The online manual for the TOPI 1.4 can be found at http://personalintelligence.info/wp-content/uploads/2014/09/TOPI-1.4-Manual-Distr-Ver2015-01-23.pdf. Coefficient alpha reliabilities for the TOPI 1.4 for the main and replication samples (see Table 2 ) were calculated based on a separate data file constructed of the cadets' item-level responses to the TOPI measure. Two subscales of the test were under exploration at the time of this work and are not included here.

3. The list of 20 talents were: (a) communicator, (b) cross-culturally fluent, (c) detailfocused, (d) innovative, (e) inspirational leader, (f) interdisciplinary, (g) interpersonal, (h) introspective, (i) logical/analytical, (j) mentally tough, (k) multi-tasker, (l) perceptive/intuitive, (m) physically fit, (n) problem-solver (o) process-disciplined, (p) project manager, (q) prudent risk-taker (r) spatially intelligence, (s) tactile/kinesthetic, and $(\mathrm{t})$ technologically adept.

4. The online system required some of the longer items on the Test of Personal Intelligence 1.4 to be shortened; the changes may have slightly depressed the performance of one subtest; an implementation error affected one item as well. We expect that these changes had negligible impact on the TOPI findings given that it has 93 items. 